\title{
ANALISIS POTENSI SIMPANAN KARBON AGROFORESTRI PERKEBUNAN KOPI ROBUSTA (COFFEA CANEPHORA) DI PEGUNUNGAN ARGOPURO, KABUPATEN BONDOWOSO
}

\author{
Elida Novita $^{\left.1^{*}\right)}$, Miftahul Nur Huda ${ }^{1)}$, Hendra Andiananta Pradana $^{2)}$ \\ ${ }^{1)}$ Teknik Pertanian, Fakultas Teknologi Pertanian, Universitas Jember \\ ${ }^{2)}$ Magister Pengelolaan Sumber Daya Alam dan Lingkungan, Pascasarjana, Universitas Jember \\ *Email:elida_novita.ftp@unej.ac.id
}

\section{ABSTRACT \\ CARBON STOCK POTENTIAL ANALYSIS OF ROBUSTA COFFEE AGROFORESTRY IN ARGOPURO MOUNTAINS, BONDOWOSO REGENCY}

Coffee plantation areas have the potential to absorb carbon dioxide in the atmosphere to reduce the greenhouse gas (GHG) emissions. Especially if coffee plantations are developed with forest plants in agroforestry area within forest management patterns. On the other hand, some coffee agroforestry now, are planted with horticultural crops that can reduce carbon sequestration ability to reduce climate change impact. The objectives of the study are to identify the parameters of the abiotic environment and the potential for carbon storage in robusta coffee agroforestry at Argopuro mountains, Bondowoso Regency. Through the calculation of plant biomass and carbon stock, it is potential to approach the amount of carbon uptake in plants to reduce carbon emissions in the atmosphere. Coffee plantation is one area that can increase carbon sequestration in the atmosphere. The results showed that microclimate parameters at robusta coffeeagroforestry at Argopuro mountains in Bondowoso regency i.e. temperature, air humidity, light intensity has average values of $29.2{ }^{\circ} \mathrm{C}$; $54 \%$; and 2166 lux respectively, then an average of soil $\mathrm{pH}$ is 6.00 . There were some commonly plants founds in robusta coffee plantation i.e mango trees, avocado trees, dadap trees, pine trees, and more banana plants. Total biomass estimation in robusta coffee plantation area is 144,834 tonnes/ha. The identification of carbon stock show that the robusta coffee agroforestry area with $2000 \mathrm{~m}^{2}$ can contribute to reduce atmospheric carbon emissions by 72.417 tonnes/ha in Argopuro mountains, Maesan District, Bondowoso Regency.

Keywords: Argopuro Mountains; Bondowoso; Carbon stock; Coffee agroforestry; Climate Change.

\section{PENDAHULUAN}

\subsection{Latar Belakang}

Hutan mengabsorpsi karbondioksida $\left(\mathrm{CO}_{2}\right)$ dari atmosfer dan mengubahnya ke dalam tubuh tanaman hidup sebagai salah satu sumber bahan organik secara alami melalui fotosintesis. Sekuestrasi (C sequestration) merupakan proses akumulasi materi organik berupa karbon (C) menjadi tubuh tumbuhan hidup. Oleh sebab itu, pengukuran jumlah C- organik dalam suatu biomassa hidup (tumbuhan) dalam luasan lahan tertentu merupakan salah satu pendekatan yang mampu menggambarkan potensi karbondioksida di atmosfer yang diabsoprsi oleh tumbuhan. Kemudian, identifikasi C dalam bagian tanaman yang telah mati atau lapuk (nekromasa) secara tidak langsung merepresentasikan karbondioksida $\left(\mathrm{CO}_{2}\right)$ yang tidak dipaparkan ke udara lewat pembakaran (Hairiah dan Subekti, 2007). Cadangan karbon ialah jumlah kandungan karbon dalam setiap pemanfaatan lahan untuk budidaya tanaman, 
serasah dan tanah (Hairiah, et al., 2011). Sejumlah karbon yang terkandung di bagian tubuh penyusun tumbuhan hidup atau biomassa pada suatu area dapat digambarkan dengan sejumlah karbondioksida di udara yang diserap oleh tanaman (Hairiah, et al., 2011).

Salah satu daerah agroforestri berbasis tanaman kopi adalah Pegunungan Argopuro di Kabupaten Bondowoso yang memiliki potensi dikembangkan menjadi kopi dengan indikasi geografis (IG certification) karena menghasilkan cita rasa kopi yang khas.. Karakteristik alam, iklim mikro dan tanaman yang tumbuh di perkebuan kopi menjadikan kawasan ini sebagai salah satu daerah penghasil kopi unggul selain kawasan lereng Ijen. Salah satu lokasi budidaya tanaman kopi yang cukup dikenal adalah Lereng Selatan Hyang Argopuro di Desa Tanah Wulan, Kecamatan Maesan, Kabupaten Bondowoso. Kemudian, menurut Sianturi dan Wachjar (2016), sebagian wilayah Lereng Hyang Argopuro yang terletak di Kabupaten Bondowoso mempunyai topografi lahan cenderung bergelombang dan berbukit-bukit. Menurut Badan Pusat Statitik (BPS) Provinsi Jawa Timur (2018), Bondowoso merupakan daerah dengan luas area tanaman perkebunan terluas nomor 4 di Wilayah Provinsi Jawa Timur. Produksi kopi tanaman kopi sejumlah 8.670 ton dengan luas lahan sekitar 12.798 ha di Tahun 2017-2018.

Pada dasarnya tanaman kopi memerlukan tanaman pendamping untuk menunjang pertumbuhan dan stabilitas tanah. Oleh sebab itu, pengembangan agroforestri dibutuhkan agar tanaman kopi dilengkapi dengan pohon-pohon hutan maupun tanaman jenis lain yang dapat berfungsi sebagai naungan. Agroforestri ialah sistem pemanfaatan lahan yang mengkombinasikan komoditi pertanian dan non-pertanian (tanaman kehutanan) guna mendukung peningkatan produktivitas dan kelestarian alam dan lingkungan (Martini, et al., 2017). Implementasi sistem agroforestri dapat menjadi solusi yang tepat untuk permasalahan perubahan iklim, karena terdapat upaya penjagaan kawasan hutan tidak memerlukan lahan baru untuk dijadikan sebagai lahan perkebunan. Langkah tersebut juga dipandang sebagai upaya penyediaan tempat simpanan karbon yang sangat dibutuhkan untuk menyerap karbondioksida di atmosfer.

Penelitian ini bertujuan untuk menentukan parameter lingkungan abiotik agroforesti perkebunan kopi robusta dan menentukan potensi simpanan karbon pada agroforesti perkebunan kopi robusta. Manfaat dari penelitian ini sebagai sumber data dan informasi bagi Dinas Lingkungan Hidup dan Kehutanan maupun Pemerintah Kabupaten Bondowoso mengenai potensi cadangan dan simpanan karbon pada agroforesti perkebunan kopi robusta, serta penelitian ini sebagai acuan untuk Dinas Lingkungan Hidup dan Kehutanan dan Pemerintah Kabupaten Bondowoso untuk memperbanyak jumlah tanaman kopi agar dan tanaman hutan sehingga dapat mendukung mitigasi dampak pemanasan global.

\section{METODOLOGI}

Studi ini dilaksanakan pada bulan April - Juli 2020. Pengambilan sampel atau contoh uji tanaman kopi robusta dilakukan di kawasan perkebunan kopi Desa Tanah Wulan, Kecamatan Maesan, Kabupaten Bondowoso, Provinsi Jawa Timur pada koordinat $113^{\circ} 44^{\prime} 1.363^{\prime \prime}$ BT dan 8 ${ }^{\circ} 1^{\prime} 8.940$ ' LS yang dapat dilihat di peta pada Gambar 1. Jumlah plot penelitian yaitu 20 plot, dengan luas 1 plot sebesar $10 \mathrm{~m}$ x $10 \mathrm{~m}$ dengan total luasan $2000 \mathrm{~m}^{2}$. Selanjutnya, penentuan nilai berat kering sampel dan analisis data dilakukan di Laboratorium Teknik Pengendalian dan Konservasi Lingkungan Jurusan Teknik Pertanian Fakultas Teknologi Pertanian Universitas Jember. Penentuan peletakan plot menggunakan metode simple random sampling. Pengambilan data dilaksanakan pada plot dengan luasan 10 meter x 10 meter. Jumlah plot yang digunakan dalam penelitian sebanyak 20 plot yang diletakan sesuai dengan bentuk lahan yang bisa diamati atau datar. Data pada penelitian ini yaitu data biomassa pohon, data parameter lingkungan abiotik (intensitas cahaya, suhu udara, pengukuran 
Analisis Potensi Simpanan Karbon Agroforestri... intensitas cahaya, kelembababn udara, $\mathrm{pH}$ Dimana : tanah, suhu tanah), data berat kering sampel pohon. Kemudian data yang didapat diolah menggunakan rumus penentuan nilai biomassa.

Nilai biomassa dan stok karbon ditentukan berdasarkan data nilai berat jenis, biomassa batang, biomassa kanopi, dan biomassa bawah (akar). Nilai berat jenis setiap pohon ditentukan dengan membagi berat kering sampel batang dengan volume batang tumbuhan (Chave et al. 2005). Nilai berat jenis ditentukan dengan menggunakan rumus 1 (Hairiyah dan Rahayu, 2007). Kemudian persamaan untuk menentukan biomassa pada tanaman, dapat dilihat pada persamaan 2-9. Setelah diperoleh data kondisi lingkungan abiotik agroforestri dan simpanan karbon pada tanaman kopi, dilakukan analisis data. Analisis data dilakukan menggunakan pendekatan deskripsi kuantitatif. Data - data tersebut disajikan dalam bentuk tabel dan dibahas sesuai dengan tujuan penelitian.

$$
\rho=\mathrm{Dw} / \mathrm{V}
$$

Dimana:

$\rho \quad=$ Berat jenis (wood density) $\left(\mathrm{g} / \mathrm{cm}^{3}\right)$

Dw = Dry weight batang $(\mathrm{g})$

$\mathrm{V}=$ Volume batang $\left(\mathrm{cm}^{3}\right)$ dimana $\mathrm{V}: \pi \mathrm{R}^{2} \mathrm{~T}$

$$
\begin{array}{ll}
\pi & =3,14 \\
\mathrm{R} & =\text { Jari-jari batang } \\
\mathrm{T} & =\text { Tinggi batang }(\mathrm{m})
\end{array}
$$$$
\mathrm{Wb}=0,0509 \times \rho \mathrm{D}^{2} \mathrm{~T}
$$

Dimana :

$\mathrm{Wb}=$ Biomassa batang $(\mathrm{kg} /$ pohon $)$

$\mathrm{D}=$ Diameter batang $(\mathrm{m})$

$\mathrm{T}=$ Tinggi batang $(\mathrm{m})$

$0,0509=$ Nilai konstanta

$$
\mathrm{Wk}=\mathrm{Vk} \times 0,5 \times \rho
$$

$\mathrm{Wk}=$ Biomassa $\mathrm{kanopi}(\mathrm{kg} /$ pohon$)$

$\mathrm{Vk}=$ Volume kanopi $\left(\mathrm{m}^{3}\right)$

$0,5=$ Nilai konstanta

$$
\mathrm{Vk}=\frac{\pi \times D b^{2}}{8} \times \% \mathrm{~K}
$$

Dimana :

$\mathrm{Db}^{2}=$ Lebar kanopi $(\mathrm{m})$

$\% \mathrm{~K}=$ Persen kanopi

$$
\mathrm{Wa}=0,2(\mathrm{~Wb}+\mathrm{Wk})
$$

Dimana :

Wa = Biomassa bawah (akar)

$0,2=$ Nilai konstanta

$\mathrm{Wb}=$ Biomassa batang

$\mathrm{Wk}=$ Biomassa kanopi

$$
\mathrm{Wp}=\mathrm{Wb}+\mathrm{Wk}+\mathrm{Wa}
$$

$$
\mathrm{Wp}_{\text {total }}=\mathrm{Wp}_{1}+\mathrm{Wp}_{2}+\mathrm{Wp}_{3}+\ldots \ldots+\mathrm{Wp}_{\mathrm{n}}(7)
$$

Dimana :

Wptotal = Biomassa total seluruh tanaman kopi

$\mathrm{Wp}_{1} \quad=$ Biomassa tanaman kopi 1

$\mathrm{Wp}_{2} \quad=$ Biomassa tanaman kopi 2

$\mathrm{Wp}_{3} \quad=$ Biomassa tanaman kopi 3

$\mathrm{Wp}_{\mathrm{n}} \quad=$ Biomassa tanaman kopi $\mathrm{n}$

$$
\mathrm{C}=0,5 \times \mathrm{Wp} \text { total }
$$

Dimana :

$\mathrm{C} \quad=$ Stok karbon

$\mathrm{Wp}=$ Biomassa total

$0,5=$ Nilai konstanta ( Winrock dalam Hernandez, 2004).

$$
\text { Biomassa }_{(\operatorname{tanaman} \text { pisang })}=0,030 \times \mathrm{D}^{2.13}
$$

Dimana :

$\mathrm{D}=$ Diameter pohon $(\mathrm{cm})$ 


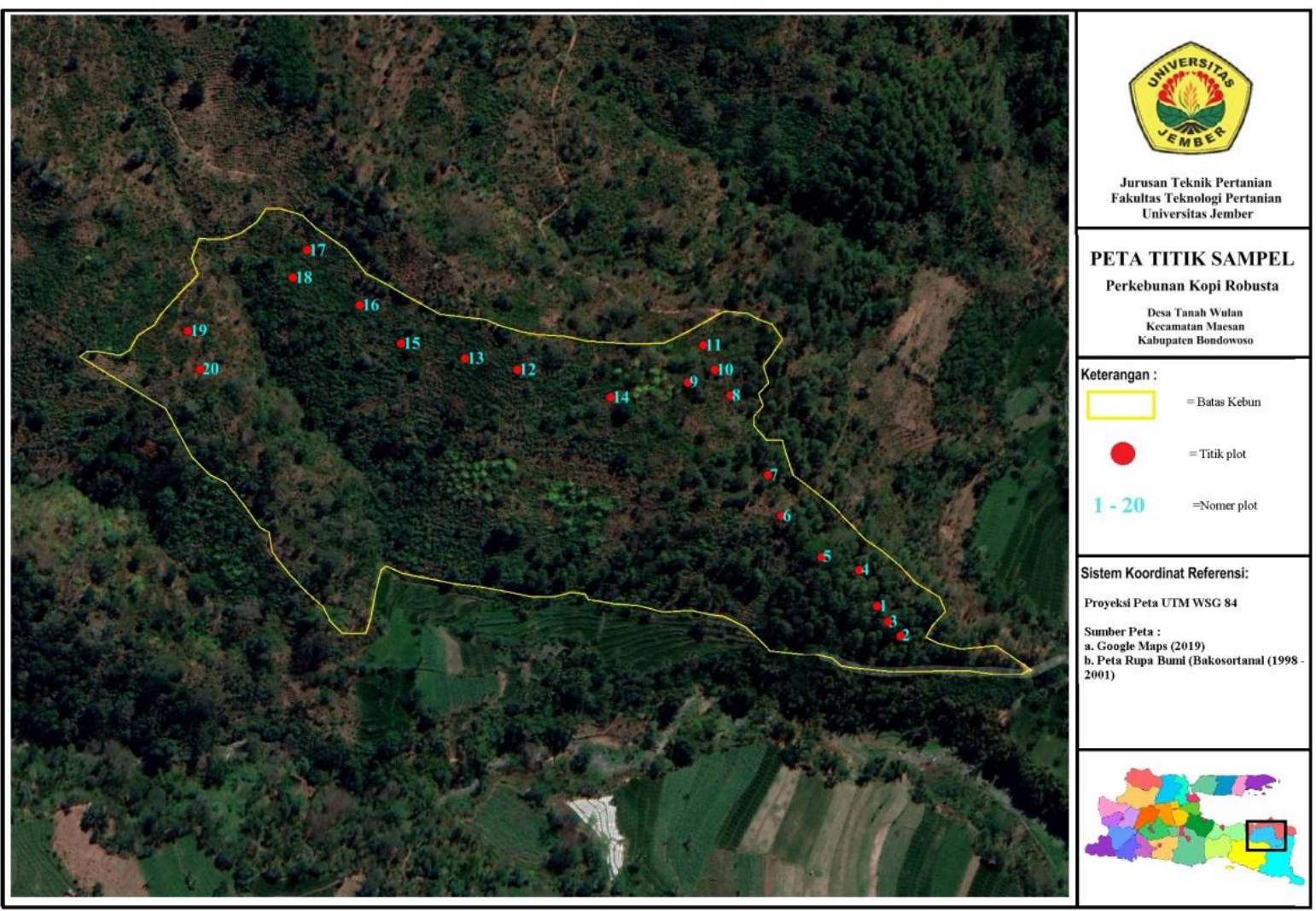

Gambar 1.

Peta Lokasi Titik Koordinat Plot Penelitian di Desa Tanah Wulan

\section{HASIL DAN PEMBAHASAN}

\subsection{Profil Kawasan Perkebunan Kopi}

Berdasarkan hasil indentifikasi pada kawasan perkebunan kopi robusta yang telah dilakukan pengamatan pada plot dengan jumlah 20 titik pada lokasi dengan luasan 1 titik $10 \mathrm{~m}$ x 10 mdengan total luasan $2000 \mathrm{~m}^{2}$. Terdapat tanaman kopi robusta sebagai tanaman pokok yang diselingi tanaman mangga, alpukat, pisang, pinus, dan dadap (cangkring) yang ditemukan pada kawasan perkebunan kopi robusta. Jumlah individu tanaman yang terindentifikasi direpresentasikan pada Tabel 1.

Data hasil penelitian menunjukan sebanyak 756 pohon pada kawasan perkebunan kopi robusta terdiri dari kopi sebanyak 684 pohon, mangga 12 pohon, alpukat 14 pohon, dadap 5 pohon, pinus 5 pohon, dan pisang 36 pohon. Perhitungan jumlah tanaman diidentifikasi pada plot $10 \mathrm{x}$ 10 meter dengan jumlah plot 20. Jenis-jenis tanaman keras yang terdapat di agroforestri perkebunan kopi diperlihatkan pada Gambar 2.

Tabel 1. Tanaman kawasan perkebunan kopi robusta

\begin{tabular}{clcc}
\hline No. & & Nama Pohon & Jumlah Pohon \\
\hline 1 & Kopi Robusta & 684 \\
2 & Mangga & 12 \\
3 & Alpukat & & 14 \\
4 & Dadap & & 5 \\
5 & Pinus & & 5 \\
6 & Pisang & Total & 36 \\
\hline & & & 756 \\
\hline
\end{tabular}


Analisis Potensi Simpanan Karbon Agroforestri... [Elida Novita, dkk]

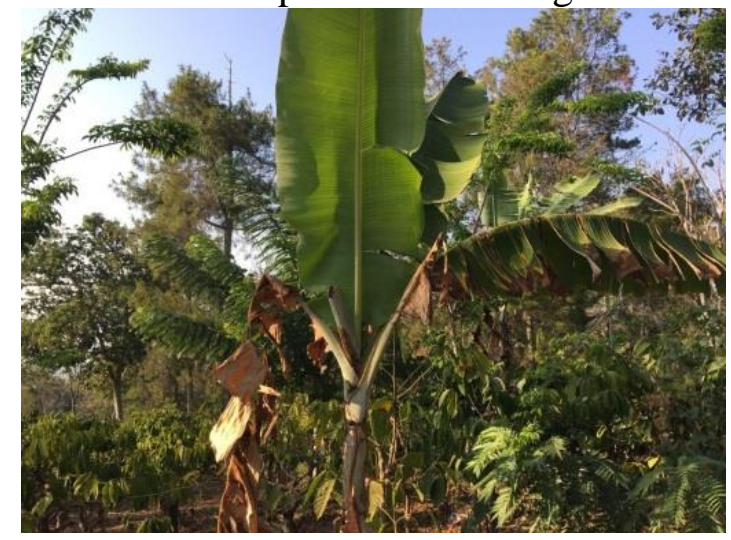

(a) Pohon pisang

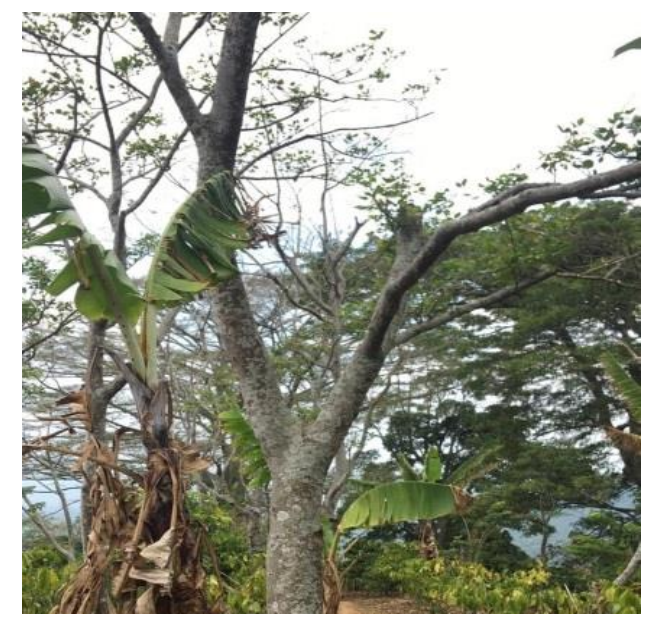

(c) Pohon dadap

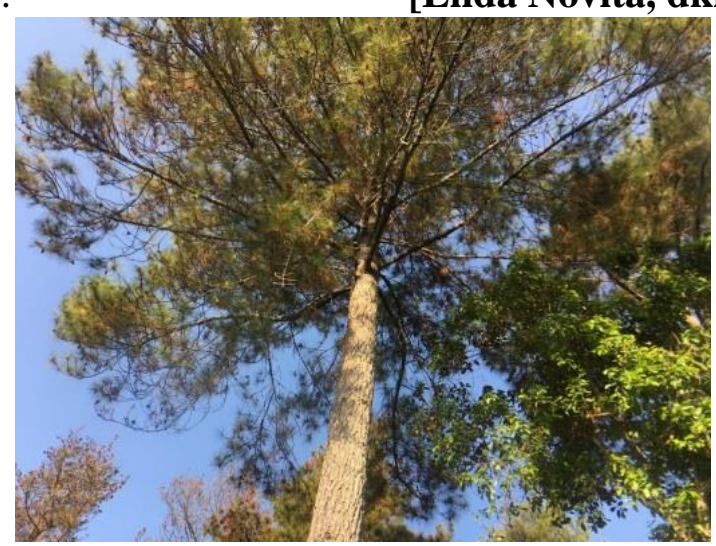

(b) Pohon pinus

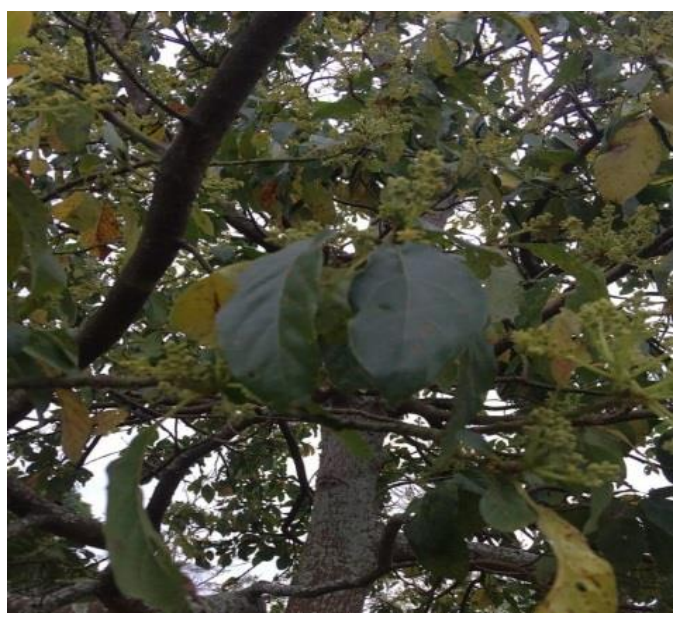

(d) Pohon alpukat

Gambar 2.

Beberapa Tanaman Keras di Agroforestri Perkebunan Kopi

\subsection{Parameter Abiotik Lingkungan pada Agroforestri Kopi}

Keberadaan jumlah tumbuhan dalam kawasan perkebunan dipengaruhi oleh kemampuan tumbuhan dalam kompetisi, kemampuan menghasilkan biji, dan penyebaran biji. Berdasarkan hasil pengukuran terhadap kondisi abiotik lingkungan menunjukkan bahwa kondisi lingkungan sekitar abiotik kawasan perkebunan kopi robusta Desa Tanah Wulan memiliki nilai rentang seperti yang disajikan pada Tabel 2.

Karakteristik tanaman kopi yakni mempunyai potensi fotosintesis yang rendah, oleh karena itu diperlukan tanaman pelindung atau naungan. Kerapatan tanaman pelindung berhubungan yang kuat dengan lama dan banyaknya cahaya yang akan diterima, kemudian intensitas cahaya matahari berkaitan dengan proses perombakan bahan organik pada tumbuhan dan aktivitas stomata tumbuhan (Nasruddin et al. 2006; Rubiyo dan Siswanto, 2012). Merujuk pada Tabel 2, intesitas cahaya sebesar 551 lux hingga 3781 lux hal ini disebabkan terdapat tanaman naungan berbagai jenis seperti pinus, dadap, mangga, pisang, alpukat yang memiliki kanopi yang lebar. Berdasarkan penelitian Rasiska (2017), intensitas cahaya matahari sebesar 986,5-6430 lux. Jumlah dan jenis tanaman naungan berfungsi untuk mengatur banyak sedikitnya cahaya bagi tanaman yang dinaungi (Handiawan et al. 2016; Yustiningsih, 2019). Hasil penelitian Utomo (2011), kopi robusta yang mendapat intensitas cahaya sebesar 35298 lux $(82,58 \%)$ memiliki kandungan glisin tertinggi, yaitu 4,995 ppm. Tingginya 169

ECOTROPHIC • 15(2): 165-175 p-ISSN:1907-5626,e-ISSN: 2503-3395 
kandungan glisin di dalam tubuh tanaman fotorespirasi (Habibi, 2009). yang mengindikasikan tanaman mengalami

Tabel 2. Hasil pengukuran parameter lingkungan abiotik

\begin{tabular}{cccc}
\hline \multirow{2}{*}{ Parameter Abiotik } & \multicolumn{2}{c}{ Nilai } & \multirow{2}{*}{ Rata-rata } \\
\cline { 2 - 3 } & Minumum & Maksimum & \\
\hline Suhu Udara $\left({ }^{\circ} \mathrm{C}\right)$ & 25,6 & 32,8 & 29,2 \\
Kelembaban Udara $(\%)$ & 35 & 73 & 54 \\
Intensitas Cahaya (lux) & 551 & 3781 & 2166 \\
pH Tanah & 5 & 7 & 6 \\
\hline
\end{tabular}

Suhu menjadi salah satu faktor penentuan terhadap pertumbuhan dan produktivitas tanaman. Apabila tanaman ditanam pada daerah yang memiliki kondisi iklim yang kurang sesuai, maka kemungkinan memiliki produktivitas dan pertumbuhan yang kurang baik (Syakur, 2011). Berdasarkan Tabel 2 ditemukan rata-rata suhu lingkungan kawasan perkebunan kopi yaitu $29,2{ }^{\circ} \mathrm{C}$ yang tergolong normal untuk proses fotosintesis dan pertumbuhan kopi. Suhu hasil pengukuran sangat mendukung untuk proses fotosintesis. Hal ini didukung oleh pertanyaan Yamori et al. (2013), suhu optimum untuk fotosintesis adalah $20-30{ }^{\circ} \mathrm{C}$. Sedangkan untuk proses kopi robusta tumbuh dan berproduksi baik pada kisaran suhu $19-32^{\circ} \mathrm{C}$ (Djaenudin et al. 2003).

Banyaknya air yang berada di udara pada suhu tertentu disebut kelembaban udara. Kondisi kelembaban yang tinggi diperlukan saat fase pembungaan. Hal ini disebabkan jika suhu udara terlalu tinggi mengakibatkan terjadinya kerontokan bunga. Kelembaban udara bersifat berbanding terbalik dengan suhu. Ketika suhu udara tinggi maka kadar air di udara dan tanah menjadi rendah karena proses penguapan. Menurut Anggara dan Marini (2011), kopi akan tumbuh dengan baik jika berada pada kelembaban udara 70-80\%, dan merupakan tanaman yang tidak tahan terhadap tiupan angin kencang, Berdasarkan Tabel 2 kelembaban udara di lahan perkebunan kopi robusta sebesar 35-73\%, berarti perkebunan kopi robusta Desa Tanah Wulan mengalami pertumbuhan yang baik.

Pengukuran $\mathrm{pH}$ tanah atau derajat keasaman tanah menunjukan nilai rata-rata 6 . Menurut Raharjeng (2015), tanaman kopi pada umumnya akan tumbuh dengan baik jika ditanam pada tanah dengan tingkat keasaman atau pH antara 5,6-6. Maka tanaman kopi pada kawasan perkebunan kopi robusta Desa Tanah Wulan sangat baik untuk tumbuh. Hal ini selaras dengan pernyataan Rejo et al. (2011), nilai derajat keasaman tanah yang sesuai untu pertumbuhan tanaman kopi adalah sekitar 5 6,5 .

\subsection{Potensi Simpanan Karbon pada Agroforestri Kopi Robusta}

\subsubsection{Berat Jenis Tanaman}

Pada kawasan perkebunan kopi robusta di Desa Tanah Wulan, terdapat tanaman selingan atau tanaman naungan seperti pohon mangga, pohon alpukat, pohon pinus dan pohon belintung. Naungan akan mempengaruhi pertumbuhan bibit tanaman kopi karena dengan menggunakan naungan akan dapat mengatur jumlah paparan cahaya matahari yang diperoleh oleh tanaman oleh sebab itu dapat mendukung pertumbuhan dan perkembangan tanaman atau tumbuhan.

Berdasarkan data pada Tabel 3 berat jenis kopi robusta sebesar $0,6448 \mathrm{~g} / \mathrm{cm}^{3}$. Sedangkan untuk naungannya seperti mangga $0,6034 \mathrm{~g} / \mathrm{cm}^{3}$, alpukat $0,4502 \mathrm{~g} / \mathrm{cm}^{3}$, pinus $0,6211 \mathrm{~g} / \mathrm{cm}^{3}$ dan dadap $0,4721 \mathrm{~g} / \mathrm{cm}^{3}$. Berat jenis tanaman kopi akan digunakan sebagai salah satu variabel pengukuran cadangan karbon dalam tanaman. Berat jenis tumbuhan merupakan variabel yang penting pada model allometrik pengukuran biomassa (Chave, et al., 2005; Hernandez, 2004). 
Tabel 3. Berat jenis tanaman di kawasan perkebunan kopi robusta

\begin{tabular}{cccc}
\hline No & Nama Pohon & Berat Jenis $\left(\mathbf{g} / \mathbf{c m}^{\mathbf{3}}\right)$ & Rata-Rata Jari-Jari Ranting $(\mathbf{c m})$ \\
\hline 1 & Kopi Robusta & 0,6448 & 0,0979 \\
2 & Mangga & 0,6034 & 0,1113 \\
3 & Alpukat & 0,4502 & 0,1223 \\
4 & Pinus & 0,6211 & 0,1145 \\
5 & Dadap & 0,4721 & 0,0866 \\
\hline
\end{tabular}

\subsubsection{Nilai biomassa dan Simpanan Karbon Berdasarkan Lokasi Penyimpanan}

Perhitungan biomassa dan stok karbon berdasarkan lokasi penyimpanan terdapat tanaman kopi robusta, mangga, alpukat, dadap, dan pinus. Berdasarkan Tabel 4 nilai biomassa tertinggi terdapat pada lokasi penyimpanan bagian batang dengan total nilai $13245,99 \mathrm{~kg}$. Tanaman pinus memiliki diameter dengan rata-rata 65,86 $\mathrm{cm}$, hal ini yang menyebabkan tanaman pinus memiliki jumlah biomassa yang tinggi dengan nilai 8391,74 ton/ha meskipun hanya dengan 5 pohon. Terbanding terbalik dengan tanaman kopi yang memiliki jumlah tanaman 684 tetapi rata-rata diameter $9,56 \mathrm{~cm}$ dengan nilai biomassa 2910,71 ton/ha. Berdasarkan pernyataan Yahmani (2013), pohon yang memiliki diameter yang lebar, juga mempunyai kandungan biomassa yang besar.

\subsubsection{Total Nilai Biomassa dan Simpanan Karbon Agroforestri Kopi Robusta}

Kalkulasi potensi simpanan karbon dilakukan berdasarkan faktor konversi dengan nilai setengah dari nilai biomassa total dari tanaman adalah unsur karbon (C) (FWI, 2009). Maka nilai total stok karbon tanaman pada kawasan perkebunan kopi robusta Desa Tanah Wulan adalah 72,42 ton/ha. Nilai total simpanan karbon perkebunan kopi robusta tersebut merupakan $50 \%$ dari total biomassanya yaitu 144,84 to/ha.
Merujuk pada Tabel 5. nilai biomassa dan simpanan karbon berbeda-beda setiap plot penelitian, nilai terbesar berada pada plot 3 dengan jumlah 44 pohon dengan nilai biomassa 41474,26 kg dan simpanan karbon $2087,13 \mathrm{~kg}$ dengan komposisi 38 tanaman kopi, 2 tanaman mangga, 3 tanaman pisang, dan 1 tanaman pinus. Kemudian, nilai terendah berada pada plot 8 dengan jumlah 39 dengan nilai biomassa $161,36 \mathrm{~kg}$ dan simpanan karbon 80,68 kg dengan komposisi 34 tanaman kopi dan 5 tanaman pisang. Berdasarkan hasil penelitian Hairiah, et al. (2011), variasi jumlah simpanan karbon dipengaruhi oleh jenis tanah, diversitas tanaman, dan pola pengolahan lahan. Sejalan dengan hal tersebut Kusmana (2015), suhu udara dan curah hujan merupakan beberapa faktor pendukung pembentukan karbon pada pohon atau tanaman.

Berdasarkan Gambar 3 menggambarkan besarnya simpanan karbon pada setiap plot dengan menujukan lingkaran warna dan besar yang berbeda. Semakin gelap warnanya semakin tinggi nilai biomassa dan semakin besar lingkaran semakin tinggi nilai biomassa. Contohnya pada plot penelitian 3 dengan komposisi 38 tanaman kopi, 2 tanaman mangga, 3 tanaman pisang, dan 1 tanaman pinus. Adapun warna semakin redup akan menunjukan nilai biomassa kecil dan semakin kecil lingkaran menunjukan nilai biomassa semakin kecil pula contohnya plot penelitian 8 dengan komposisi 34 tanaman kopi dan 5 tanaman pisang. 
Tabel 4. Nilai biomassa dan stok karbon berdasarkan bagian pohon

\begin{tabular}{lccccccc}
\hline & $\begin{array}{c}\text { Rata- } \\
\text { Nata }\end{array}$ & \multicolumn{3}{c}{ Biomassa (kg) } & \multicolumn{3}{c}{ Karbon (kg) } \\
\cline { 3 - 8 } & $\begin{array}{c}\text { Diameter } \\
\text { Batang }\end{array}$ & batang & kanopi & Akar & batang & kanopi & Akar \\
\hline Kopi Robusta & 9,56 & 2910,71 & 280,66 & 638,27 & 1455,35 & 140,33 & 319,14 \\
Mangga & 22,32 & 894,26 & 28,37 & 184,53 & 447,13 & 14,18 & 92,26 \\
Alpukat & 23,45 & 1005,59 & 17,88 & 204,69 & 502,79 & 8,94 & 102,35 \\
Dadap & 18,66 & 43,70 & 0,61 & 8,86 & 21,85 & 0,30 & 4,43 \\
Pinus & 65,86 & 8391,74 & 218,63 & 1722,07 & 4195,87 & 109,31 & 861,04 \\
\hline & & 13245,99 & 546,15 & 2758,43 & 6623,00 & 273,08 & 1379,21 \\
\hline
\end{tabular}

Tabel 5. Nilai biomassa dan simpanan karbon kawasan perkebunan kopi robusta

\begin{tabular}{clccc}
\hline No. & Nama Pohon & Jumlah & Biomassa (ton/ha) & Karbon (ton/ha) \\
\hline 1 & Kopi Robusta & 684 & 19,15 & 9,57 \\
2 & Mangga & 12 & 5,54 & 2,77 \\
3 & Alpukat & 14 & 6,14 & 3,07 \\
4 & Dadap & 5 & 0,27 & 0,13 \\
5 & Pinus & 5 & 51,66 & 25,83 \\
6 & Pisang & 36 & 62,08 & 31,04 \\
\hline & Total & 756 & 144,84 & 72,42 \\
\hline
\end{tabular}

Tabel 6. Nilai biomassa dan simpanan karbon berdasarkan plot penelitian

\begin{tabular}{|c|c|c|c|c|c|c|c|c|c|}
\hline \multirow{2}{*}{ Plot } & \multicolumn{6}{|c|}{ Jumlah Tanaman } & \multirow{2}{*}{ Total } & \multirow{2}{*}{$\begin{array}{c}\text { Biomassa } \\
(\mathrm{kg})\end{array}$} & \multirow{2}{*}{$\begin{array}{c}\text { Karbon } \\
(\mathrm{kg})\end{array}$} \\
\hline & Kopi & Mangga & Alpukat & Dadap & Pisang & Pinus & & & \\
\hline 1 & 32 & & 2 & & & 2 & 36 & 3634,12 & 1817,06 \\
\hline 2 & 37 & & 1 & 1 & & & 39 & 306,94 & 153,47 \\
\hline 3 & 38 & 2 & & & 3 & 1 & 44 & 4174,26 & 2087,13 \\
\hline 4 & 32 & 1 & 2 & & 2 & & 37 & 1216,36 & 608,18 \\
\hline 5 & 37 & 1 & & 1 & & 1 & 40 & 3491,94 & 1745,97 \\
\hline 6 & 36 & & 1 & 2 & 2 & & 41 & 679,19 & 339,59 \\
\hline 7 & 34 & & 3 & & & 1 & 38 & 698,67 & 349,33 \\
\hline 8 & 34 & & & & 5 & & 39 & 161,36 & 80,68 \\
\hline 9 & 32 & & 1 & 1 & & & 34 & 248,29 & 124,15 \\
\hline 10 & 33 & & 1 & & & & 34 & 3133,65 & 1566,82 \\
\hline 11 & 35 & 2 & & & 2 & & 39 & 2277,54 & 1138,77 \\
\hline 12 & 36 & 2 & & & 1 & & 39 & 1989,63 & 994,81 \\
\hline 13 & 32 & 2 & & & 1 & & 35 & 478,26 & 239,13 \\
\hline 14 & 32 & & & & 1 & & 33 & 362,40 & 181,20 \\
\hline 15 & 35 & 1 & & & 5 & & 41 & 1062,72 & 531,36 \\
\hline 16 & 33 & 1 & 1 & & 2 & & 37 & 640,10 & 320,05 \\
\hline 17 & 33 & & & & 1 & & 34 & 302,55 & 151,27 \\
\hline 18 & 38 & 1 & & & 7 & & 46 & 1717,19 & 858,60 \\
\hline 19 & 34 & & & & 3 & & 37 & 702,88 & 351,44 \\
\hline 20 & 31 & & 1 & & & 1 & 33 & 1688,70 & 844,35 \\
\hline & & & Total & & & & 756 & 28966,74 & 14483,37 \\
\hline
\end{tabular}




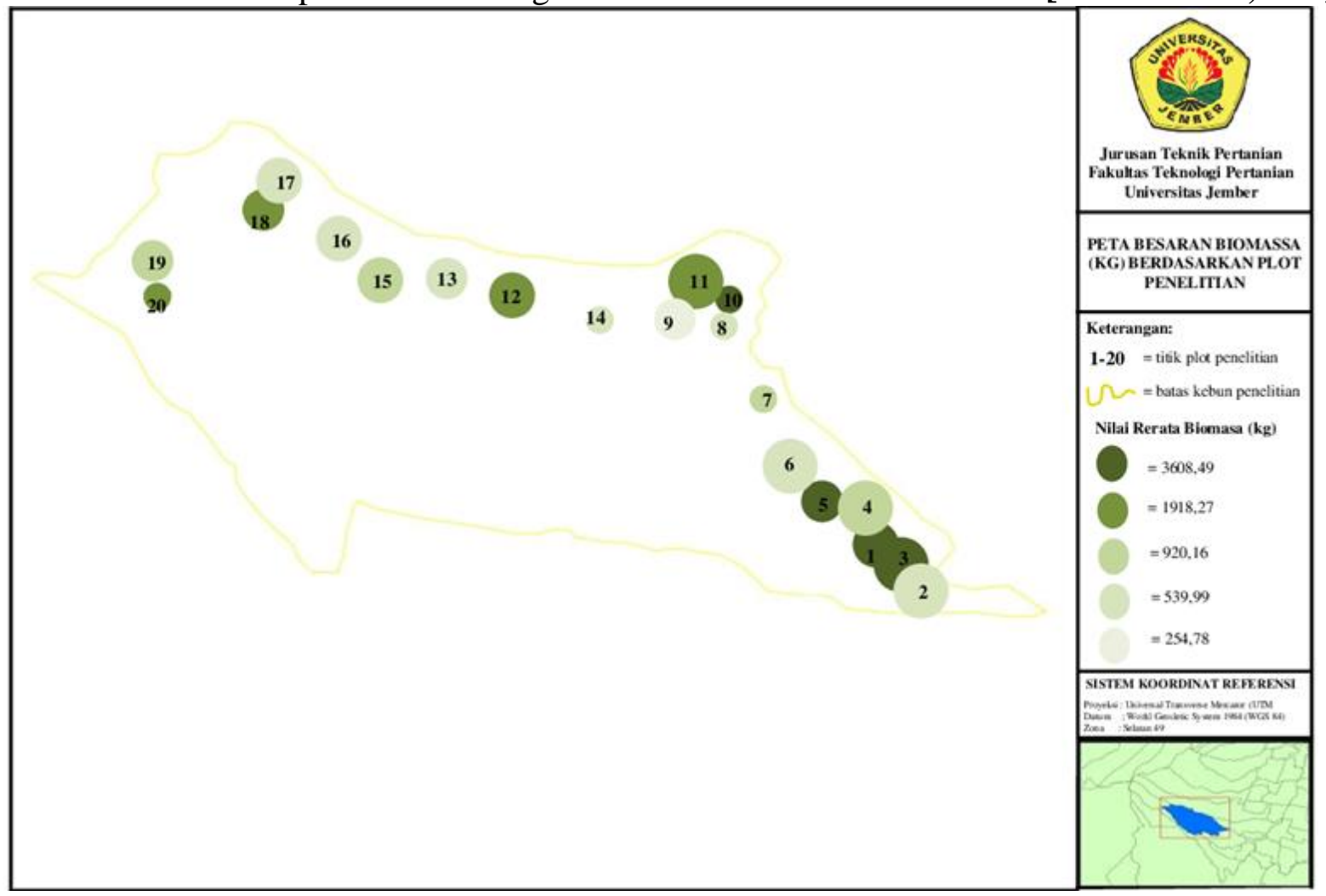

Gambar 3.

Peta Besaran Biomassa berdasarkan Plot Penelitian

\section{SIMPULAN DAN SARAN}

\subsection{Simpulan}

Kajian terhadap parameter lingkungan abiotik di agroforestri perkebunan kopi menunjukkan nilai rata rata suhu $29,2{ }^{\circ} \mathrm{C}, \mathrm{RH}$ atau kelembaban udara 54 semakin\% nilai rerata intensitas cahaya 2166 lux dan nilai rerata $\mathrm{pH}$ tanah 6 . Menunjukan bahwa agroforestri perkebunan kopi robusta sangat baik untuk perkembangan tumbuh tanaman kopi robusta. Hasil perhitungan diperoleh nilai biomassa pada agroforestri perkebunan kopi robusta dengan luasan $2000 \mathrm{~m}^{2}$ adalah sebesar 144,834 ton/ha, kemudian nilai simpanan karbon sebesar 72,417 ton/ha dihasilkan dari tanaman kopi robusta, mangga, alpukat, pinus, dan pisang. Hasil perhitungan diperoleh nilai biomassa dan stok karbon pada batang pohon sebesar dengan total $1324,59 \mathrm{~kg}$.

\subsection{Saran}

Terdapat peluang lanjutan kajian dari penelitian yang sudah dilakukan yaitu (1) pengukuran tinggi batang dan kanopi pada penelitian ini dilakukan dengan mengunakan tongkat dan estimasi visual. Penelitian selanjutnya diharapkan dapat mengunakan metode yang lebih akurat. (2) Pencatatan titik kordinat diharapkan pada penelitian selanjutnya dapat dilakukan dengan pencatatan kordinat pada setiap individu untuk mendapatkan data lokasi individu tumbuhan yang telah dihitung biomassannya.

\section{DAFTAR PUSTAKA}

Anggara, A., Marini, S. 2011. Kopi Si Hitam Menguntungkan Budi Daya dan Pemasaran. Cahaya Atma Pustaka, Yogyakarta.

Badan Pusat Statistik (BPS) Provinsi Jawa Timur. 2018. Luas Areal Perkebunan Menurut Kabupaten Dalam Angka 
2018. Surabaya, BPS Provinsi Jawa Timur.

Chave, J., Andalo, C., Brown, S., Cairns, M.A., Chambers, J.Q., Eamus, D., Lescure, J.P. 2005. Tree allometry and improved estimation of carbon stocks and balance in tropical forests. Oecologia, 145(1): 87-99.

Djaenudin, U.D., Marwan H., Subagyo H., Hidayat. 2003. Kriteria Kesesuaian Lahan Untuk Komoditas Pertanian. Bogor: Pusat Penelitian Tanah dan Agroklimat.

FWI, 2009. Penghitungan Potensi Karbon Di Kawasan Hutan. Lampung.

Habibi P. 2009. "Kajian Fotorespirasi pada Kopi Robusta dengan Naungan Berbeda" (tesis). Jember: Universitas Jember.

Hairiah, K., Subekti, S. 2007. Pengukuran Karbon Tersimpan di Berbagai Macam Penggunaan Lahan. World Agroforestry Centre, ICRAF Southeast Asia, Bogor.

Hairiah, K., Ekadinata, A., Sari, R. R., Rahayu, S. 2011. Pengukuran Cadangan Karbon dari Tingkat Lahan ke Bentang Lahan Edisi ke 2. Bogor: Agroforestry Centre.

Handriawan, A., Respatie, D.W., Tohari. 2016. Pengaruh intensitas naungan terhadap pertumbuhan dan hasil tiga kultivar kedelai (Gilcine max (L.) Merrill) di Lahan Pesisir pantai Bugel, Kulon Progo. Vegetalika, 5(3): 1-14.

Hernandez, R.P. 2004. Assessing Carbon Stocks And Modelling Win-Win Scenarios of Carbon Sequestration Through Land-Use Changes. Vol. 1. Food and Agriculture Organization of United Nation.

Kusmana, C. 2015. Pengelolaan hutan mangrove yang berkelanjutan dan terintegrasi. Jurnal Pengelolaan Sumberdaya Alam dan Lingkungan, 5(1): 1-6.
Martini, E, Riyandoko, Roshetko, J.M. 2017. Pedoman Membangun Agroforestri Kopi. Bogor: World Agroforestry Centre (ICRAF) Southeast Asia Regional Program.

Nasruddin, Musa, Y., Kuruseng, MA. 2006. Aktivitas beberapa proses fisiologi tanaman kakao muda di lapang pada berbagai naungan buatan. Jurnal Agrisistem, 2(1):25-33.

Raharjeng, A.R.P. 2015. Pengaruh faktor abiotik terhadap hubungan kekerabatan tanaman Sansevieria trifasciata L. Jurnal Biota, 1(1): 33-41.

Rasiska, S. 2017. Efek tiga jenis pohon penaung terhadap keragaman serangga pada pertanaman kopi di Perkebunan Rakyat Manglayang, Kecamatan Cilengkrang, Kabupaten Bandung. Jurnal Agrikultura, 28(3): 161-166.

Rejo, A., Rahayu, S., Panggabean, T. 2011. "Karakteristik Mutu Biji Kopi pada Proses

Dekafeinasi"'(skripsi). Palembang: Universitas Sriwijaya.

Rubiyo, Siswanto. 2012. Peningkatan produksi dan pengembangan kakao (Theobroma cacao L.) di Indonesia. Buletin RISTRI, 3(1): 33-48.

Sianturi, V. F., Wachjar, A. 2016. Pengelolaan pemangkasan tanaman kopi arabika (Coffea arabica L.) di Kebun Blawan, Bondowoso, Jawa Timur. Buletin Agrohorti, 4(3): 266-275.

Syakur, A. 2011. Analisis iklim mikro di dalam rumah tanaman untuk memprediksi waktu pembungaan dan matang fisiologis tanaman tomat dengan menggunakan metode Artificial Neural Network. Agroland: Jurnal Ilmu-ilmu Pertanian, 18(2): 97-103.

Utomo S.B. 2011. "Dinamika Suhu Udara Siang-Malam terhadap Fotorespirasi Fase Generatif Kopi Robusta di Bawah Naungan yang Berbeda pada Sistem 
Analisis Potensi Simpanan Karbon Agroforestri...

[Elida Novita, dkk]

Agroforestri”(skripsi). $\quad$ Jember: $\quad$ Yamori, W., Hikosaka, K., Way .D.A. 2013. Universitas Jember. Respon suhu fotosintesis pada tanaman

Yahmani, A. 2013. Studi kandungan karbon pada hutan alam sekunder di hutan pendidikan mandiangin Fakultas Kehutanan Unlam. Jurnal Hutan C3, C4, dan CAM. Resum Fotosintesis, 10(10): 159- 168 .

Tropis, 1(1): 85-91.

Yustiningsih, M. 2019. Intensitas cahaya dan efisiensi fotosintesis pada tanaman naungan dan tanaman terpapar cahaya langsung. Bioedu, 4(2): 43-48. 